\title{
Microelements as diagnostic markers of pancreatic cancer
}

\author{
Marcin Lener ${ }^{1 *}$, Anna Wiechowska-Kozłowska², Magdalena Muszyńska³ ${ }^{3}$ Katarzyna Jaworska-Bieniek, \\ Grzegorz Sukiennicki ${ }^{1}$, Katarzyna Kaczmarek', Tomasz Gromowski', Wojciech Marciniak ${ }^{3}$, Anna Jakubowska', \\ Jan Lubiński ${ }^{1,3}$
}

From Annual Conference on Hereditary Cancers 2014

Szczecin, Poland. 25-26 September 2014

\section{Introduction}

Pancreatic cancer is the eighth most commonly diagnosed cancer in the developed world and has one of the worst prognoses of any malignancy with $98 \%$ succumbing to their disease within 5 years. Little is known about the etiology of the disease despite significant new insights into the mutation signatures common this disease. Changes in microelements serum levels are reported in pancreatic cancer. In the current study we have examined the levels of $\mathrm{Se}, \mathrm{Cu}, \mathrm{Fe}, \mathrm{Zn}$ and $\mathrm{Mg}$ in a moderately sized pancreatic cancer population and compared it to a healthy agematched population.

\section{Material and methods}

A total of 84 pancreatic cancer patients and 84 agedmatched healthy controls were enrolled in the study after providing informed consent. The patients with pancreatic cancer were enrolled to the study from the Hospital of the Ministry of Internal Affairs and Administration in Szczecin, Poland. For each pancreatic cancer patient included in this study an unaffected individual registered in International Hereditary Cancer Center, Pomeranian Medical University of Szczecin, was used as a control.

Each person enrolled in the study donated $\sim 10 \mathrm{ml}$ EDTA blood for sufficient serum to be isolated and examined for the elements $\mathrm{Se}, \mathrm{Cu}, \mathrm{Fe}, \mathrm{Zn}$ and $\mathrm{Mg}$. The level of $\mathrm{Se}, \mathrm{Cu}, \mathrm{Fe}, \mathrm{Zn}$ and $\mathrm{Mg}$, in the serum was determined by mass spectrometry Inductively Coupled Plasma Mass Spectrometry (Elan DRC-e, PerkinElmer).

\footnotetext{
* Correspondence: marcinlener@poczta.onet.pl

'Department of Genetics and Pathology, International Hereditary Cancer

Center, Pomeranian Medical University, Szczecin, Poland

Full list of author information is available at the end of the article
}

Table 1 The correlation between serum Se level and the occurrence of pancreatic cancer.

\begin{tabular}{llllll}
\hline $\begin{array}{l}\text { Cancer } \\
\text { site }\end{array}$ & Quartile & $\begin{array}{l}\text { Se level } \\
(\boldsymbol{\mu} \mathbf{g} / \mathbf{l})\end{array}$ & $\begin{array}{l}\text { No. of cancer / } \\
\text { controls }\end{array}$ & OR & $\begin{array}{l}\boldsymbol{p} \text { - } \\
\text { value }\end{array}$ \\
\hline Pancreas & I & $29.87-55.40$ & $37 / 5$ & 1 & - \\
\cline { 2 - 6 } & II & $55.90-67.97$ & $31 / 11$ & 2.62 & 0.1635 \\
\cline { 2 - 6 } & III & $68.06-79.20$ & $9 / 33$ & 27.13 & $<0.0001$ \\
\cline { 2 - 6 } & IV & $79.36-137.47$ & $7 / 35$ & 37 & $<0.0001$ \\
\hline
\end{tabular}

Table 2 The correlation between serum $\mathrm{Cu}$ level and the occurrence of pancreatic cancer.

\begin{tabular}{llllll}
\hline $\begin{array}{l}\text { Cancer } \\
\text { site }\end{array}$ & Quartile & $\begin{array}{l}\text { Cu level } \\
(\boldsymbol{\mu g} / \mathbf{l})\end{array}$ & $\begin{array}{l}\text { No. of cancer / } \\
\text { controls }\end{array}$ & OR & $\begin{array}{l}\mathbf{p}- \\
\text { value }\end{array}$ \\
\hline Pancreas & I & $\begin{array}{l}695.06- \\
1023.95\end{array}$ & $9 / 32$ & 1 & - \\
\cline { 2 - 6 } & II & $\begin{array}{l}1025.88- \\
1175.73\end{array}$ & $14 / 27$ & 1.84 & 0.3256 \\
\cline { 2 - 6 } & III & $1179.38-$ & $22 / 19$ & 4.11 & 0.0058 \\
& & 1421.96 & & & \\
\cline { 2 - 7 } & IV & $1448.68-$ & $37 / 4$ & 32.8 & $<0.0001$ \\
& 2901.35 & & & & \\
\hline
\end{tabular}

Table 3 The correlation between serum Fe level and the occurrence of pancreatic cancer.

\begin{tabular}{llllll}
\hline $\begin{array}{l}\text { Cancer } \\
\text { site }\end{array}$ & Quartile & $\begin{array}{l}\text { Fe level } \\
(\boldsymbol{\mu} \mathbf{g} / \mathbf{l})\end{array}$ & $\begin{array}{l}\text { No. of cancer / } \\
\text { controls }\end{array}$ & OR & $\begin{array}{l}\mathbf{p}- \\
\text { value }\end{array}$ \\
\hline Pancreas & I & $\begin{array}{l}138.88- \\
668.75\end{array}$ & $29 / 12$ & 1 & - \\
\cline { 2 - 6 } & II & $\begin{array}{l}672.81- \\
921.18\end{array}$ & $19 / 22$ & 2.79 & 0.0429 \\
\cline { 2 - 6 } & III & $\begin{array}{l}931.41- \\
1245.91\end{array}$ & $13 / 29$ & 5.39 & 0.0004 \\
& IV & $1247.89-$ & $22 / 20$ & 2.19 & 0.1151 \\
& 1631.56 & & & & \\
\hline
\end{tabular}


Table 4 The correlation between serum $\mathrm{Zn}$ level and the occurrence of pancreatic cancer.

\begin{tabular}{llllll}
\hline Cancer site & Quartile & Zn level $(\boldsymbol{\mu g} / \mathbf{l})$ & No. of cancer / controls & OR & p- value \\
\hline Pancreas & I & $306.12-760.79$ & $23 / 18$ & 1 & - \\
\cline { 2 - 6 } & II & $765.29-863.96$ & $14 / 27$ & 2.46 & 0.0752 \\
\cline { 2 - 6 } & III & $864.59-995.08$ & $21 / 21$ & 1.27 & 0.6620 \\
\cline { 2 - 6 } & IV & $995.84-1890.96$ & $25 / 17$ & 0.86 & 0.8257 \\
\hline
\end{tabular}

Table 5 The correlation between serum $\mathrm{Mg}$ level and the occurrence of pancreatic cancer.

\begin{tabular}{llllll}
\hline Cancer site & Quartile & Mg level $(\boldsymbol{\mu g} / \mathbf{l})$ & No. of cancer / controls & OR & p- value \\
\hline Pancreas & I & $11964.63-18616.02$ & $25 / 16$ & 1 & - \\
\cline { 2 - 7 } & II & $18673.87-20144.41$ & $18 / 23$ & 1.99 & 0.1843 \\
\cline { 2 - 7 } & III & $20274.88-21673.70$ & $17 / 24$ & 2.20 & 0.1215 \\
\cline { 2 - 7 } & IV & $21775.80-30676.08$ & $22 / 19$ & 1.34 & 0.6555 \\
\hline
\end{tabular}

\section{Results}

\section{Conclusions}

1. There is a very strong correlation between the level of selenium, copper in serum and the occurrence of pancreatic cancers in the Polish population. 2. The $\mathrm{Se}, \mathrm{Cu}$ level in serum may be a useful diagnostic tool of pancreatic cancer.

3. Further investigations are needed to determine if $\mathrm{Se}, \mathrm{Cu}$ levels can be used in:

a. differential diagnosis between pancreatic cancer (PC) and non-malignant pancreatic lesions b. monitoring of systemic treatment efficiency in PC

c. identification of prognostic factors of pancreatic tumors

d. identification of factor of PC causative

\section{Authors' details}

${ }^{1}$ Department of Genetics and Pathology, International Hereditary Cancer Center, Pomeranian Medical University, Szczecin, Poland. '2Division of Health Care Ministry of Internal Affairs and Administration in Szczecin, Poland. ${ }^{3}$ Read

- Gene, S.A., Grzepnica, Poland.

Published: 26 November 2015

Submit your next manuscript to BioMed Central and take full advantage of:

- Convenient online submission

- Thorough peer review

- No space constraints or color figure charges

- Immediate publication on acceptance

- Inclusion in PubMed, CAS, Scopus and Google Scholar

- Research which is freely available for redistribution 